\title{
THE FORMULATION OF PRODUCTION HOUSE STRATEGY AND COMPETITIVENESS
}

\author{
Retno Dewanti ${ }^{1 *}$. Ashrida Dwi Handayani ${ }^{1}$, Shankar Addi Mehra ${ }^{2}$, Hasan Ghazali ${ }^{1}$ \\ ${ }^{1}$ Bina Nusantara University, Indonesia, ${ }^{2}$ Film Maker 3amnstillrolling, India \\ retnodewanti@binus.edu
}

\begin{abstract}
The aim of this study related community development is a lesson learn that to know how the internal factors and external factors impacted on Production House management. PT. Putra Kusuma Pictures Indonesia which provides services to in-house productions, by using IFE Matrix, EFE Matrix and CPM Matrix for researching Production house' business strategy in the input phase, which will then be followed by the matching stage which uses SWOT Matrix, IE Matrix and Grand Strategy Matrix. The alternative analysis for Production house was completed using the Blue Ocean Strategy, which has surpassed the Four Action Framework (Eliminate-Reduce-Raise-Create), and the three good strategies which consist of focus, divergence and a good motto. Techniques used in data collection involve direct interview with the head of the company. This study in competitive strategy shows that the best strategy that should be applied by the company is through product development, while the alternative strategy that could be developed as a leading product is through social culture themed films.
\end{abstract}

Keywords: Business strategy, SWOT analysis, blue ocean strategy, production house

\section{INTRODUCTION}

Today the trend of globalization has increasingly touched human life with marked rapid technology development. In addition, the demands of modern society for entertainment services and facilities are increasingly large. From the development of film and market technology, it provides opportunities for various film industries and television companies to continue to increase their existence. Based on previous research by Rasit et al (2015), it is stated that film plays an important role to influence behavior compared to other media.

One of the benefits of film is directly related to education to the community on the challenge to oppose violence against women conducted by research by Ruangnapakul, et al, 2018; BernardHoverstad, 2013 stated that film is a good medium for education against violence against women. In this context the film supports SDG goal number 3 namely gender equality. Based on data from UNO in 2017 that based on the survey in 2005-2016, there were 87 countries with 19 percent of women aged 15-49 years experiencing physical and sexual violence (sustainabledevelopment.un.org). Based on the existing issue, it becomes the idea of developing a narrative film in order to participate in saving the Earth, people and its environment.

Film workers face the challenge of adapting the message delivered and also technology based on needs and also the challenges of competition between production houses that are increasingly growing to compete in producing films. The current demand is to produce a strategy to improve its competitiveness in the industry. Many of the production houses have collaborated with cinematography from other countries to enrich the presentation of the aired stories and strengthen the technical delivery of the film as well as the technology used so as to get proper attention in the film market.

Films are not merely entertainment products, they are also cultural products. One of the film's contributions is to become the root of a nation's creativity growth, Effendy (2014). Films can also change the image of a nation in the eyes of the international community if used properly. With the social and cultural mission and the film business itself, a PH needs to produce a strategy. The method of producing competitive strategies and new strategies discussed in this article will provide thinking and learning for film workers and other art workers to be able to survive in their business and develop new ideas in reaching their markets. 


\section{METHOD}

This study uses descriptive research method with internal and external environment analysis methods sourced from David (2011) namely Input Phase (IFE, EFE, CPM), Matching Phase (SWOT, IE, Grand Strategy) and Decision Phase (QSPM), and added with the method known as Blue Ocean Strategy by Kim (2014) and Yang, et al (2011).

\section{RESULT \& DISCUSSION}

\section{Input Phase}

Table 1. IFE Matrix Results

\begin{tabular}{|l|l|c|c|c|}
\hline \multicolumn{1}{|c|}{ Internal Factors } & Quality & \multicolumn{2}{c|}{ Rank } & Score \\
\hline Strengths & 0.178 & 4 & 0.712 \\
\hline S1 & Have its own shooting equipment & 0.134 & 3 & 0.402 \\
\hline S2 & Films produced are always aired in cinemas & 0.089 & 3 & 0.267 \\
\hline S3 & Maintain good relations with work partners & 0.070 & 4 & 0.280 \\
\hline S4 & Always produce the latest films every year & 0.073 & 3 & 0.219 \\
\hline S5 & Track Record & 0.059 & 1 & 0.059 \\
\hline Weaknesses & 0.082 & 1 & 0.082 \\
\hline W1 & Website is not available yet & 0.098 & 2 & .0 .196 \\
\hline W2 & Cash Flow is not current & 0.141 & 2 & 0.282 \\
\hline W3 & Very limited publication program & 0.076 & 2 & 0.152 \\
\hline W4 & Films produced are less desirable & $\mathbf{1}$ & & $\mathbf{2 . 6 5 1}$ \\
\hline W5 & Company management is not efficient & & 2 \\
\hline
\end{tabular}

Based on the results of the IFE Matrix, PH has an internally strong advantage.

Table 2. EFE Matrix Results

\begin{tabular}{|c|c|c|c|c|}
\hline No & External Factors & Quality & Rank & Score \\
\hline \multicolumn{5}{|c|}{ Opportunities } \\
\hline 01 & Cooperation offers with other PHs & 0.095 & 3 & 0.285 \\
\hline $\mathbf{O 2}$ & $\begin{array}{l}\text { The emergence of demand for film production } \\
\text { variants from new tv stations }\end{array}$ & 0.180 & 4 & 0.720 \\
\hline $\mathbf{O 3}$ & Changes in the film genre of the community & 0.117 & 3 & 0.351 \\
\hline $\mathbf{O 4}$ & $\begin{array}{l}\text { Provisions from the government in supporting } \\
\text { Indonesian films }\end{array}$ & 0.067 & 3 & 0.201 \\
\hline $\mathbf{O 5}$ & The emergence of demands for new cinemas & 0.129 & 3 & 0.387 \\
\hline \multicolumn{5}{|c|}{ Threats } \\
\hline T1 & $\begin{array}{l}\text { The emergence of new competitors with PH } \\
\text { status }\end{array}$ & 0.092 & 1 & 0.092 \\
\hline $\mathbf{T 2}$ & $\begin{array}{l}\text { Foreign film technology is more popular with } \\
\text { Indonesian people }\end{array}$ & 0.083 & 2 & 0.166 \\
\hline
\end{tabular}




\begin{tabular}{|c|l|c|c|c|}
\hline No & \multicolumn{1}{|c|}{ External Factors } & Quality & Rank & Score \\
\hline T3 & $\begin{array}{l}\text { The number of imported films entering } \\
\text { Indonesia }\end{array}$ & 0.122 & 3 & 0.244 \\
\hline T4 & $\begin{array}{l}\text { Weak Indonesian government regulations that } \\
\text { protect film Copyright }\end{array}$ & 0.063 & 3 & 0.189 \\
\hline T5 & Lack of film schools in Indonesia & 0.052 & 3 & 0.156 \\
\hline TOTAL & $\mathbf{1}$ & & $\mathbf{2 . 7 9 1}$ \\
\hline
\end{tabular}

Based on the results of the EFE Matrix, PHs may take advantage of the opportunities available to minimize existing threats from the external environment.

Table 3. CPM Matrix Results

\begin{tabular}{|c|c|c|c|c|c|c|c|}
\hline \multirow[t]{2}{*}{ Factors } & \multirow[t]{2}{*}{ Quality } & \multicolumn{2}{|c|}{$\begin{array}{c}\text { PT. Putra Kusuma } \\
\text { Pictures }\end{array}$} & \multicolumn{2}{|c|}{$\begin{array}{l}\text { PT. Nasi Putih } \\
\text { Production }\end{array}$} & \multicolumn{2}{|c|}{$\begin{array}{c}\text { PT. Armoto } \\
\text { Insang Gemilang }\end{array}$} \\
\hline & & Rating & Score & Rating & Score & Rating & Score \\
\hline Film Innovations & 0.081 & 3 & 0.243 & 4 & 0.324 & 3 & 0.243 \\
\hline Business Capital & 0.144 & 4 & 0.576 & 4 & 0.576 & 4 & 0.576 \\
\hline $\begin{array}{l}\text { Production } \\
\text { Quality }\end{array}$ & 0.115 & 3 & 0.345 & 4 & 0.460 & 3 & 0.345 \\
\hline $\begin{array}{l}\text { Company } \\
\text { Reputation }\end{array}$ & 0.082 & 3 & 0.246 & 3 & 0.246 & 1 & 0.082 \\
\hline Technology used & 0.122 & 3 & 0.366 & 3 & 0.366 & 3 & 0.366 \\
\hline Marketing & 0.068 & 2 & 0.136 & 3 & 0.204 & 3 & 0.204 \\
\hline $\begin{array}{l}\text { Comopany } \\
\text { Management }\end{array}$ & 0.136 & 3 & 0.408 & 3 & 0.408 & 2 & 0.272 \\
\hline Market Share & 0.061 & 3 & 0.183 & 3 & 0.183 & 1 & 0.061 \\
\hline Track record & 0.058 & 3 & 0.174 & 3 & 0.174 & 1 & 0.058 \\
\hline $\begin{array}{l}\text { Financial } \\
\text { Position }\end{array}$ & 0.133 & 3 & 0.399 & 3 & 0.399 & 3 & 0.399 \\
\hline TOTAL & 1 & & 3.076 & & 3.340 & & 2.606 \\
\hline
\end{tabular}

Based on the consideration of elements from Assauri (2013) adapted into the CPM Matrix, this case study shows that PH under PT. White Rice Production is superior to its competitive profile. 


\section{Matching Phase}

Table 4. SWOT Matrix Results

\begin{tabular}{|c|c|c|}
\hline & Strengths (S) & Weaknesses (W) \\
\hline & $\begin{array}{l}\text { 1. Have its own shooting } \\
\text { equipment } \\
\text { 2. Films produced are } \\
\text { always aired in cinemas } \\
\text { 3. Maintain good relations } \\
\text { with work partners } \\
\text { 4. Always produce the latest } \\
\text { films every year } \\
\text { 5. Track Record }\end{array}$ & $\begin{array}{l}\text { 1. Website is not available } \\
\text { yet } \\
\text { 2. Cash Flow is not current } \\
\text { 3. Publication programs that } \\
\text { supports film marketing } \\
\text { are still limited } \\
\text { 4. Films produced are less } \\
\text { desirable } \\
\text { 5. Company management is } \\
\text { not efficient }\end{array}$ \\
\hline Opportunities (O) & SO Strategies & WO Strategies \\
\hline $\begin{array}{l}\text { 1. Cooperation offers with } \\
\text { other PHs } \\
\text { 2. The emergence of demand } \\
\text { for film production variants } \\
\text { from new tv stations } \\
\text { 3. Changes in the film genre of } \\
\text { the community } \\
\text { 4. Provisions from the } \\
\text { government in supporting } \\
\text { Indonesian films } \\
\text { 5. The emergence of demands } \\
\text { for new cinemas }\end{array}$ & $\begin{array}{l}\text { 1. Increase creative and } \\
\text { innovative film production } \\
\text { (S2, S3, O2, O3) } \\
\text { (Product Development) } \\
\text { 2. Rent shooting equipment } \\
\text { (S1, O1) } \\
\text { (Backward Intergration) }\end{array}$ & $\begin{array}{l}\text { Create a website so that the } \\
\text { community and work } \\
\text { partners more easily get } \\
\text { information about the } \\
\text { company } \\
\text { (W1, W3, O1) } \\
\text { (Market Penetration) }\end{array}$ \\
\hline Threats (T) & ST Strategies & WT Strategies \\
\hline $\begin{array}{l}\text { 1. The emergence of new } \\
\text { competitors with PH status } \\
\text { 2. Foreign film technology is } \\
\text { more popular with } \\
\text { Indonesian people } \\
\text { 3. The number of imported } \\
\text { films entering Indonesia } \\
\text { 4. Weak Indonesian } \\
\text { government regulations that } \\
\text { protect film Copyright } \\
\text { 5. Lack of film schools in } \\
\text { Indonesia }\end{array}$ & $\begin{array}{l}\text { Make a film school } \\
\text { (S3, T5) } \\
\text { (Backward Intergration) }\end{array}$ & $\begin{array}{l}\text { Produce various kinds of new } \\
\text { films or TV programs with } \\
\text { up-to-date technology } \\
\text { (W4, T1, T3) } \\
\text { (Product Development) }\end{array}$ \\
\hline
\end{tabular}

Based on the results of SWOT Matrix, alternative strategies are obtained, namely product development, market penetration, and backward integration (Al-Araki, 2013). 


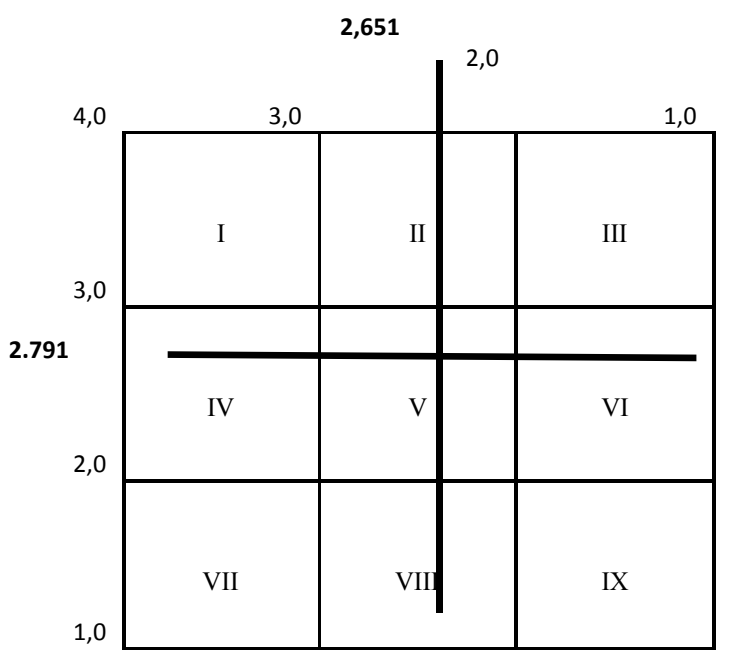

Figure 1. IE Matrix Results

Based on the results of IE Matrix, alternative strategies are obtained, namely market penetration and product development.

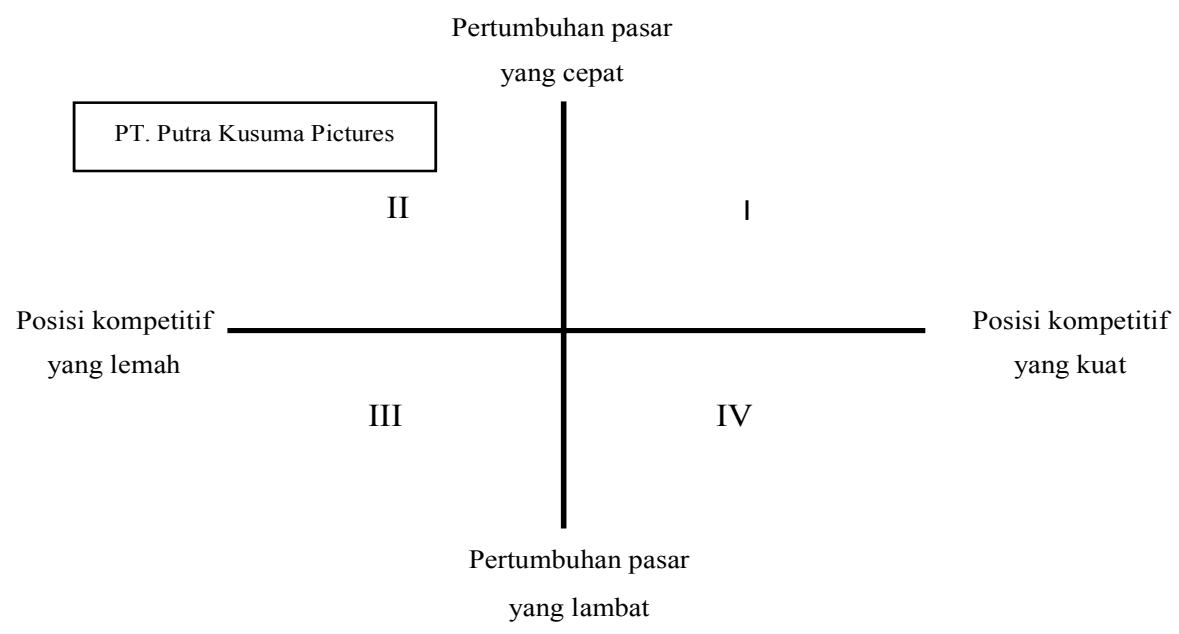

Figure 2. Grand Strategy Matrix Results

Based on the Grand Strategy Matrix, alternative strategies are obtained, namely market development, market penetration, product development, horizontal integration, divestment and liquidation.

\section{CONCLUSION}

\section{Decision Phase}

Based on the calculation of the alternative frequency of the above strategies, the most emerging alternative strategies are: Product development, Market penetration and Backword integration. Furthermore, alternative strategies are analyzed for the decision phase using QSPM Matrix. From the results of the Strategic Planning Matrix (QSPM) on PHs, it is known that market penetration strategy has a total value of attraction of 5,204, Product Development strategy has a total attraction value of 
6.603, and Backword integration strategy has a total attraction value of 3,294. So the most appropriate strategy recommendation to be applied by PHs to improve competitiveness is Product Development Strategy (Solihin, 2012). The results of this strategy are then developed using Blue Ocean strategy so that new innovations and creativity can be implemented.

\section{Alternative Strategies for PHs using Four-Step Framework}

The blue ocean strategy itself is a strategy that provides a different view that is out of alternatives that have been used by competitors in trying to win the competition (Josef, 2014; Kim \& Mauborgne, 2014). The famous concept in Blue Ocean is the creation of new markets for non-consumers. To create a four-step framework, a discussion of four important factors in creating a value curve is done by reducing and eliminating sources of expenditure and increasing and creating new values within the company.

1. The following is the design of alternative strategies using four-step framework:

a. In the Eliminate element, companies should be able to eliminate the excessive use of funds.

b. In the Reduce element, companies should be able to reduce the frequency of film production each year with the same genre.

c. In the Increase element, companies should increase the quality of film production and services to work partners.

d. In the Create element, companies should create innovations to films that wil be produced and create new unique tv programs, create website that supports information on the company, and create marketing programs.

\section{Alternative Strategy Fulfillment in 3 Characteristics of a Good Strategy}

Based on the fulfillment of alternative strategies with three good strategies in the Blue Ocean, they are described as follows:

- Focus, seen through the blue ocean strategy built into the framework to have details such as the elimination of the use of funds to save costs, improve the quality of film production, and create unique film innovations and new television programs as well as specific objectives such as focusing on which segment to choose.

- Divergence/Motion Moving away, seen through the way PHs provide cultural elements and adds moral messages that are shown through the films that have been made.

- In an enchanting Motto, PHs use the tagline "Not an Ordinary Production House" to give the idea that this production house not only makes films, but also can make advertisements and public services.

\section{REFERENCES}

Al-Araki, Magid. 2013. SWOT analysis revisited through PEAK-framework. Journal of Intelligent \& Fuzzy Systems 25 615-625 DOI:10.3233/IFS-120668 IOS Press.

Assauri, S. 2013. Strategic Management Sustainable Competitive Advantage (Edisi2.). Jakarta: PT. Raja Grafindo.

Bernard-Hoverstad, A. (2013). Framing Perceptions of Violence against Women in Film:"Les silences du palais" and "Incendies.".

David, Fred R., (2011), Strategic Management, 13 th Edition, Published by Prentice Hall.

Effendy, Heru. 2014. Mengawali Industri Film Indonesia. Jakarta: KPG (Keperpustakaan Populer Gramedia).

Josef Benny Rohy, Abd. Rahman Kadir, Syamsu Alam. 2014. Blue Ocean Strategy Untuk Menetapkan New Business Canvas Model pada PT Pelabuhan Indonesia IV. 
Kim, Chan. W., Mauborgne, Renee. (2014). Blue Ocean Strategy. Jakarta: PT. Serambi IlmuSemesta Rasit, R. M., Hamjah, S. H., Tibek, S. R., Sham, F. M., Ashaari, M. F., Samsudin, M. A., \& Ismail, A. (2015). Educating film audience through social cognitive theory reciprocal model. ProcediaSocial and Behavioral Sciences, 174, 1234-1241.

Ruangnapakul, N., Yusof, N., \& Hamid, N. A. (2018). Perspectives on violence against women in Thai film: The Eternity. Kasetsart Journal of Social Sciences.

Solihin, Ismail. 2012. Manajemen Strategik. Jakarta: Erlangga.

Yang, Chow-Chow, King-Jang Yang. 2011. An integrated model of value creation based on the refined Kano's model and the blue ocean strategy. Total Quality Management Vol. 22, No. 9, September 2011, 925-940. 